\title{
Recapitulation of primary nailing in open diaphyseal fractures of tibia
}

\section{Pradeepkumar Theeppainthan, Thayumana Sundaram*, Prabhakaran Anbalagan, Selvakumar Pandiyan, Chitarth Rajasekaran, Hemnath Pandiyan}

Department of Orthopaedics, Mahatma Gandhi Medical College and Research Institute, Puducherry, India

Received: 28 August 2019

Revised: 17 September 2019

Accepted: 21 September 2019

\section{*Correspondence:}

Dr. Thayumana Sundaram,

E-mail: uwithvasanth@gmail.com

Copyright: ( ) the author(s), publisher and licensee Medip Academy. This is an open-access article distributed under the terms of the Creative Commons Attribution Non-Commercial License, which permits unrestricted non-commercial use, distribution, and reproduction in any medium, provided the original work is properly cited.

\begin{abstract}
Tibia fractures are the commonest long bone fracture, most commonly resulting from high velocity injury. We investigated whether primary nailing in open tibia fractures were producing satisfactory outcomes and we compared the outcomes in terms of fracture union and rates of infection. We identified 202 citations related to our searches from our key words, out of which 89 were original articles, which were eligible and others were case reports and review articles. We found 4 from these references which had the parallel inclusion criteria and were reviewed. All 4 studies had almost similar time period for the fracture union. Infection rates in this study were directly related to the severity of the grade of injury, which were commonly experienced in grade III injuries. In conclusion, our analysis had no significant difference in postoperative healing duration, implant failure rates, postoperative infection and secondary operation rates in primary nailing for open tibia fractures.
\end{abstract}

Keywords: Primary nailing, Tibia, Open fractures

\section{INTRODUCTION}

Tibia fractures are the commonest long bone fractures, most commonly resulting from high velocity injury. There has been an exponential increase in vehicles in India in the last decade, which has ultimately become the most common cause for high velocity injury. Tibia being a superficial bone has become vulnerable for such injuries. Injuries occurring here are classified based on soft tissue injury as open or closed. ${ }^{1}$ Open tibial fractures are often associated with severe soft tissue and bone injury. ${ }^{2}$ The management of open fractures is regarded as an orthopaedic emergency. ${ }^{3}$ The primary objective in managing an open fracture is union with prevention or eradication of wound sepsis. ${ }^{4}$ In orthopaedic traumatology, the method of soft tissue stabilization and skeletal stabilization are still debated. ${ }^{5}$ Intramedullary nailing in open fractures of the tibia is a well-accepted treatment modality in the developing world. References are scanty regarding the incidence of infection or nonunion related to specific type of open injury with this background. ${ }^{6}$ In this review, we investigated whether primary nailing in compound tibia fractures were producing satisfactory outcomes and we compared the outcomes in terms of fracture union and rates of infection.

\section{METHODS}

The inclusion criteria in this study were research literatures that were published; adult patients with open tibia fractures of Gustilo types I, II, IIIA, and IIIB, except for Gustilo type IIIC; all randomized controlled clinical trials; and the interventional studies on primary nailing and their outcomes on fracture union and rate of infections. 
Exclusion criteria in this study were the literature research of an insufficient number of patients in treatment and control groups, case reports or review, observational studies, and non-randomized controlled trials.

Search method, employed for the identification of studies were from PubMed, ProQuest and Cochrane Library, from the period of January 2000 to December 2018. The keywords that we used were 'primary nailing', 'open tibia fractures'. In addition, we also performed hand searching of information for search strategy. Content experts were asked to identify additional potentially relevant studies.

The quality of assessment was made using Jadad scale. ${ }^{7}$ The evaluation was done according to the type of study, patient population, mode of intervention, and the outcomes. The studies were assessed by two reviewers independently. Disagreements that arise were resolved by discussion between them and settled by a third reviewer. The Jadad scale score of literatures of more than 3 was considered high quality with a maximum of 5 .

The data extracted included the factors concerned to bony union, which are the failure of progression of fracture healing over a period of at least 3 months, rates of infection, both deep and superficial, were collected.

\section{DESCRIPTION OF STUDIES}

We identified 202 citations related to our searches from our key words, out of which 89 were original articles and others were case reports and review articles. We found 4 from these references which have the parallel inclusion criteria such as study population, age, grade of injury, pattern of fracture and the average follow up.

Table 1: Characteristics of the patients and fractures.

\begin{tabular}{|c|c|c|c|c|c|}
\hline \multicolumn{2}{|l|}{ Authors } & Choudhary et $\mathrm{al}^{8}$ & Seron et al $^{9}$ & Abdelaal et al ${ }^{10}$ & Joshi et al ${ }^{11}$ \\
\hline \multicolumn{2}{|c|}{ Study population } & 31 & 74 & 55 & 56 \\
\hline \multicolumn{2}{|l|}{ Men } & 28 & 63 & 44 & 52 \\
\hline \multicolumn{2}{|c|}{ Age (years) } & $37(18-70)$ & $33(16-67)$ & $33.2(25-65)$ & $30(16-72)$ \\
\hline \multirow{4}{*}{ Grade } & I & - & 16 & 17 & 30 \\
\hline & II & 15 & 38 & 17 & 18 \\
\hline & IIIA & 12 & 20 & 14 & 4 \\
\hline & IIIB & 4 & - & 7 & 4 \\
\hline \multirow{4}{*}{ Pattern } & Transverse & 8 & 32 & 17 & 35 \\
\hline & Oblique & 9 & 7 & 17 & 11 \\
\hline & Comminuted & 12 & 30 & 21 & 10 \\
\hline & Segmental & 1 & 5 & - & - \\
\hline \multicolumn{2}{|c|}{ Follow up } & Upto 24 months & 18 months (7-32) & 39 months (18-56) & 20 months (18-24) \\
\hline
\end{tabular}

Table 2: Complications.

\begin{tabular}{|c|c|c|c|c|c|}
\hline Complications & & Infections & Delayed union & $\begin{array}{l}\text { Non } \\
\text { union }\end{array}$ & $\begin{array}{l}\text { No. of revision } \\
\text { surgery }\end{array}$ \\
\hline \multirow{4}{*}{ Choudhary et al $^{8}$} & Grade I & - & - & & \multirow{4}{*}{3} \\
\hline & Grade II & $1 \mathrm{~S}$ & 19.4 weeks & & \\
\hline & Grade IIIA & $1 \mathrm{~S}$ & 23.3 weeks & & \\
\hline & Grade IIIB & $2 \mathrm{D}$ & 30.5 weeks & & \\
\hline \multirow{3}{*}{ Seron et $\mathbf{a l}^{9}$} & Grade I & $1 \mathrm{~S}$ & 15.5 weeks & & \multirow{3}{*}{2} \\
\hline & Grade II & $4 \mathrm{~S}, 3 \mathrm{D}$ & 17.3 weeks & - & \\
\hline & Grade IIIA & $3 \mathrm{~S}, 2 \mathrm{D}$ & 17.8 weeks & & \\
\hline \multirow{4}{*}{ Abdelaal et al $^{10}$} & Grade I & $5 \mathrm{~S}$ & 13 (<6 months), 12 (6-12 months) & - & \multirow{4}{*}{9} \\
\hline & Grade II & $9 \mathrm{~S}, 1 \mathrm{D}$ & $\begin{array}{l}4 \text { ( }<6 \text { months), } 8 \text { (6-12 months), } 1 \\
\text { (>1 year) }\end{array}$ & - & \\
\hline & Grade IIIA & 9S, 3D & $\begin{array}{l}2 \text { (<6 months), } 6 \text { (6-12 months), } \\
3 \text { (>1 year) }\end{array}$ & 1 & \\
\hline & Grade IIIB & $4 S, 3 D$ & 2 (6-12 months), 4 (>1 year) & 2 & \\
\hline \multirow{4}{*}{ Joshi et al ${ }^{11}$} & Grade I & - & 30 (<32 weeks) & & \multirow{4}{*}{10} \\
\hline & Grade II & $4 \mathrm{~S}$ & 4 (>32 weeks) & & \\
\hline & Grade IIIA & $2 \mathrm{~S}, 2 \mathrm{D}$ & 2 (>32 weeks) & & \\
\hline & Grade IIIB & 4D & 4 (<32 weeks) & & \\
\hline
\end{tabular}

S- Superfecial, D- Deep. 


\section{THE POSTOPERATIVE HEALING RATES IN PATIENTS WITH FRACTURE}

All the four studies reported the effect of primary nailing for compound diaphyseal fractures of tibia. An au fait analysis was made between the groups and we observed almost similar time period for the fracture to unite. Delay in union was correlating directly with the grade of injury in each reference. Some of these patients underwent secondary procedure as dynamization, for improved fracture union for certain patients.

\section{THE POSTOPERATIVE INFECTION}

All the four studies reported infection, more evident in Grade III compound fractures. All superficial and deep wound infections were identified differentiated and managed accordingly. Fractures failing to show any clinical or roentgenographic evidence of healing by 3 months after injury were considered to have delayed union. The complications (infection, delayed union, and secondary surgeries) encountered in each study group are listed in Table 2.

\section{DISCUSSION}

Tibia fractures are one of the commonest fractures encountered in high velocity trauma. At present, early and repeated wound debridement, immediate rigid skeletal stabilization, and early wound coverage in combination with antibiotic therapy are the preferred treatment modality for open tibia fractures. The methods used for skeletal stabilization for these injuries still remains debated, with several options such as intramedullary rods, bone plates, external fixations, and intramedullary nailing. ${ }^{12-18}$

Donally et al showed $28.6 \%$ of incidence of infection in his study for primary nailing in compound tibia fractures, $22 \%$ was seen in Henkelmann et al and $25 \%$ in Mudiganty et al and $30.3 \%$ in Wei et al. ${ }^{19-22}$ Smokers had a relatively increased risk of infection and delayed wound healing in other studies, $24.7 \%$ has been documented by Hao et al. ${ }^{22}$ In our review, personal habits such as smoking, substance abuse and comorbidities such as diabetes and hypertension were not discussed. Operative duration didn't influence significantly in infection rate and there was no significant difference in timing of surgery among these references. The time duration between the injury and operative intervention was from $<8$ hours to 48 hours in these studies. The initial basic interventions play more of a role in limiting the risk of infections. ${ }^{23}$ In general, prolonged operative duration has an increased chance of surgical site infection of $13 \%$, $17 \%$ and $37 \%$ for every $15 \mathrm{mins}, 30 \mathrm{mins}$ and $60 \mathrm{~min}$ of surgery Cheng et al. ${ }^{24}$

Brown et al reported union time of 36.7 weeks in his study. ${ }^{25}$ Union occurred between 34.2 weeks in Olerud et al and 38.1 weeks in Chan et al, all three had used external fixators for open fractures of tibia. ${ }^{26,27}$ In this series nailing resulted in better union rates. Delayed union was noted up to $18.5 \%$ in Fong et al and $18.95 \%$ in Mehmood et al. ${ }^{28,29}$ Factors which influenced delayed union in this review was grade of injury. In a study by Westgeest et al with a study of 736 subjects concluded that higher Gustilo grade fractures were associated with non-union and delayed union. ${ }^{30}$ Delayed union was equally encountered in operative duration of surgery $>60$ mins and <60 mins. Other studies also showed similar result with not much significant difference in the operative duration Lua et al. ${ }^{31}$ In literature distal $1 / 3^{\text {rd }}$ fractures were reported with delayed union because of the poor blood supply compared to proximal $1 / 3^{\text {rd }}$ due to absence of muscle attachment at distal $1 / 3^{\text {rd }}$ of tibia. A study by Teitz et al had $26 \%$ delayed union with intact fibula. ${ }^{32}$ This is due to the tibiofibular discrepancy that occurs and cause altered strain patterns in the tibia and fibula.

A routine dynamization was not done in this studies. Dynamization was done in cases where no signs of union were present at 6 weeks to 12 weeks who were on appropriate follow up in each study. Patients who underwent dynamization showed signs of union on their next follow-ups.

There were also other factors, which influenced delayed fracture union and the chances of infection. These were delay in early debridement, injury-surgery interval, duration of surgery, associated injuries, personal habits, comorbidities such as hypertension, diabetes and other medical conditions, which were not evaluated in these studies.

There were also other complications in the intraoperative period, early and late postoperative periods during the management of these fractures, for which further studies are still required. The economic burden drastically influences the patient's surgical outcome with open tibia fractures. In this review article one study showed no significant difference in the costs of index hospital stay, index procedure, and fracture-associated medications; however, the re-operation costs have to be considered based on the types of complications.

The results showed that there was no significant difference between these similar studies in the postoperative healing rates, secondary operation, and implant failure and infection events in primary nailing of open tibia fractures in postoperative recovery.

\section{CONCLUSION}

In conclusion, our study had no significant difference in postoperative healing duration, implant failure rates, postoperative infection and secondary operation rates in primary intramedullary nailing for open tibia fractures treatment. However, because of the above mentioned limitations, the results of this review should be cautiously 
taken into account, and long term follow-up and a larger sample size of high-quality randomized control trials are needed.

\section{Limitations}

Our findings are mainly limited by the quality and number of studies included. Limited study sample which might be insufficient for significant data. Two articles had limited number of patients less than 100, which can result in low statistical efficiency. Other factors including medical technology, the equipment used, and the judgment index may also influence the evaluation system.

Funding: No funding sources

Conflict of interest: None declared

Ethical approval: Not required

\section{REFERENCES}

1. Briel M, Sprague S, Heels-Ansdell D, Guyatt G, Bhandari M, Blackhouse $\mathrm{G}$, et al. Economic evaluation of reamed versus unreamed intramedullary nailing in patients with closed and open tibial fractures: results from the Study to Prospectively Evaluate Reamed Intramedullary Nails in Patients with Tibial Fractures (SPRINT). Value Health. 2011;14:450-7.

2. Melvin JS, Dombroski DG, Torbert JT, Kovach SJ, Esterhai JL, et al. Open tibial shaft fractures: I. Evaluation and initial wound management. J Am Acad Orthop Surg. 2010;18:10-9.

3. Fischer MD, Gustilo RB, Varecka T. The timing of flap coverage, bone-grafting, and intramedullary nailing in patients who have a fracture of the tibial shaft with extensive soft-tissue injury. J Bone Joint Surg Am. 1991;73:1316-22.

4. Gustilo RB, Anderson JT. Prevention of infection in the treatment of on thousand and twenty five open fractures of long bones: retrospective and prospective analyse. JBJS Am. 1976;58:453-8.

5. Gustilo RB, Mendoza RM, Williams DN. Problems in the management of type 3 (Severe) open fractures: a new classi cation of type 3 open fractures. J Trauma. 1984;24:742-6.

6. Bone LB, Johnson KD. Treatment of tibial fractures by reaming and intramedullary nailing. J Bone Joint Surg. 1986;68:877-87.

7. Jadad AR, Moore RA, Carroll D, Jenkinson C, Reynolds DJM, Gavaghan DJ, et al. Assessing the quality of reports of randomized clinical trials: is blinding necessary? Control Clin Trials. 1996; 17:1-12.

8. Choudhary BM, Amer S, Kumar RD, Vanchi PK. Management of Open Tibial Shaft Fractures Treated By Primary Intramedullary Interlocking Nailing. IOSR-JDMS. 2015;14:52-6.

9. Seron S, Rasool MN. Outcomes of intramedullary nailing for open fractures of the tibial shaft. SA Orthop J. 2018;17(1):24-9.
10. Abdelaal M, Kareem S. Open Fracture Tibia Treated by Unreamed Interlocking Nail. Long Experience in El-Bakry General Hospital. Open J Orthop. 2014;4:60-9.

11. Joshi D, Ahmed A, Krishna L, Lal Y. Unreamed interlocking nailing in open fractures of tibia. J Orthop Surg (Hong Kong). 2004;12(2):216-21.

12. Keating JF, O'Brien PJ, Blachut PA, Meek RN, Broekhuyse HM. Locking intramedullary nailing with and without reaming for open fractures of the tibial shaft. J Bone Joint Surg. 1997;79:334-41.

13. Bach AW, Hansen ST. Plates versus external fixation in severe open tibial shaft fractures: A randomized trial. Clin Orthop Relat Res. 1989;241:89-94.

14. Henley MB, Chapman JR, Agel J, Harvey EJ, Whorton AM, Swiontkowski MF. Treatment of II, IIIA and IIIB open fractures of the tibial shaft: A prospective comparison of unreamed interlocking intramedullary nails and half-pin external fixators. J Orthop Trauma. 1998;12:1-7.

15. Hobrook JL, Swiontkowski MF, Sanders R. Treatment of open fractures of the tibial shaft: Ender nailing versus external fixation: A randomized, prospective comparison. J Bone Joint Surg Am. 1989;71:1231-9.

16. Tornetta P, Bergman M, Watnik N, Berkowitz G, Steuer J. Treatment of grade IIIB open tibial fractures: A prospective randomized comparison of external fixation and non-reamed locked nailing. J Bone Joint Surg Br. 1994;76:13-9.

17. Wanson TV, Spiegel JD, Sutherland TB, Bray TJ, Chapmann MW. A prospective evaluation of the Lottes nail versus external fixation in 100 open tibial fractures. Orthop Trans. 1990;14:716.

18. Finkemeier CG, Schmidt AH, Kyle RF, Templeman DC, Varecka TF. A prospective, randomized study of intramedullary nails inserted with and without reaming for treatment of open and closed fractures of the tibial shaft. $\mathrm{J}$ Orthop Trauma. 2000;14:187-93.

19. Donnally CJ, Lawrie CM. Primary Intra-Medullary Nailing of Open Tibia Fractures Caused by LowVelocity Gunshots: Does Operative Debridement Increase Infection Rates? Surgical Infections. 2018;19(3):273-7.

20. Henkelmann R, Frosch KH, Glaab R, Lill H, Schoepp C, Seybold D, et al. Infection following fractures of the proximal tibia. A systematic review of incidence and outcome. BMC Musculoskelet Disord. 2017;18(1):481.

21. Mudiganty S, Daolagupu AK. Treatment of infected non-unions with segmental defects with a rail fixation system. Strategies Trauma Limb Reconstr. 2017;12(1):45-51.

22. Singh A, Jiong-Hao JT, Wei DT, Liang CW, Murphy D, Thambiah J. Gustilo IIIB Open Tibial Fractures: An Analysis of Infection and Nonunion Rates. Indian J Orthop. 2018;52(4):406-10. 
23. Young S, Lie SA. Risk Factors for Infection after 46,113 Intramedullary Nail Operations in Low- and Middle-income Countries. World J Surg. 2013;37(2):349-55.

24. Cheng H, Chen BP. Prolonged Operative Duration Increases Risk of Surgical Site Infections: A Systematic Review. Surg Infect (Larchmt). 2017;18(6):722-35.

25. Court Brown CM, Christie J, McQueen MM. Closed Intramedullary Tibial Nailing: Its use in closed and Type I open fractures. J Bone Joint Surg. 1990;72B:605-11.

26. Karlström G, Olerud S. Ipsilateral fracture of the femur and tibia. J Bone Joint Surg Am. 1977;59:240-3.

27. Lefaivre KA, Guy P, Chan H, Blachut PA. Longterm follow-up of tibial shaft fractures treated with intramedullary nailing. $\mathrm{J}$ Orthop Trauma. 2008;22(8):525-9.

28. Fong K, Truong V. Predictors of non-union and reoperation in patients with fractures of the tibia: an observational study. BMC Musculoskelet Disord. 2013;14:103.

29. Mehmood M, Deshpande S, Khan SM, Singh PK, Patil B, Rathi R. Epidemiology of Delayed Union of Long Bones. J Trauma Treat. 2017;6:370.

30. Weber WJ. Factors Associated With Development of Nonunion or Delayed Healing After an Open Long Bone Fracture: A Prospective Cohort Study of 736 Subjects. J Orthop Trauma. 2016;30(3):149-55.

31. Lua JYC, Tan VH, Sivasubramanian H, Kwek EBK. Complications of Open Tibial Fracture Management: Risk Factors and Treatment. Malaysian Orthop J. 2017;11:18-22.

32. Teitz C, Carter C, Dennis H, Frankel V. Problems associated with tibial fractures with intact fibulae. J Bone Joint Surg. 1980;62:770-6.

Cite this article as: Theeppainthan $\mathrm{P}$, Sundaram $\mathrm{T}$, Anbalagan P, Pandiyan S, Rajasekaran C, Pandiyan H. Recapitulation of primary nailing in open diaphyseal fractures of tibia. Int J Res Orthop 2019;5:1226-30. 